\title{
The Role of Prostate-Specific Antigen in Prostate Cancer Screening
}

\author{
Rolul antigenului specific al prostatei în \\ screeningul cancerului de prostată
}

\section{Traian Vasile Constantin ${ }^{1 *}$, Victor Lucian Mădan², Maria-Magdalena Constantin³, Silviu-Horia Morariu ${ }^{4}$, Bogdan Braticevici ${ }^{5}$}

\section{University of Medicine and Pharmacy "Carol Davila", Bucharest}

2. University of Medicine and Pharmacy "Carol Davila", Bucharest, Clinic of Urology, SMC

3. University of Medicine and Pharmacy "Carol Davila", Bucharest, 2nd Clinic of Dermatology, Colentina Clinical Hospital

4. University of Medicine and Pharmacy Tg. Mures, Clinic of Dermatology

5. University of Medicine and Pharmacy "Carol Davila", Bucharest, Clinic of Urology, "Prof. Dr. Th. Burghele” Clinical Hospital

\begin{abstract}
Prostate cancer is, after lung cancer, the most common malignant disease diagnosed in the male population. The introduction into the practice used during the 80's and 90's of the determination of serum Prostate-Specific Antigen (PSA) levels, as a component of screening for prostate cancer, was a turning point in the medical practice. Due to this enzyme produced exclusively by the prostate gland, the prostate cancer detection rate (in curative, intracapsular stages) improved significantly. Serum PSA is a better predictive factor for prostate cancer (PC) than digital rectal examination or transrectal prostatic ultrasound.
\end{abstract}

Keywords: Prostate-specific antigen, prostate cancer, benign prostatic hyperplasia

\section{Rezumat}

Cancerul de prostată reprezintă, după cancerul pulmonar, cea mai frecventă afecţiune malignă diagnosticată $\hat{\imath}$ cadrul populaţiei masculine. Introducerea în practica curentă în anii 80-90 a determinării Antigenului Specific al Prostatei (PSA) seric, ca şi componentă a screeningului pentru cancerul de prostată, a reprezentat un moment de răscruce în practica medicală. Datorită acestei enzime produsă exclusiv de către glanda prostatică, rata detecţiei cancerului de prostată (în stadii curative, intracapsulare) s-a îmbunătăţit semnificativ. PSA-ul seric reprezintă un factor predictiv pentru cancerul de prostată (CP) mai bun decât tuşeul rectal sau ecografia prostatică transrectală.

Cuvinte cheie: Antigenul specific al prostate, cancer de prostată, hiperplazia benignă de prostată

Received: 16 ${ }^{\text {th }}$ January 2014; Accepted: $1^{\text {st }}$ June 2014; Published: $9^{\text {th }}$ June 2014.

*Corresponding author: Traian Vasile Constantin, University of Medicine and Pharmacy "Carol Davila", Bucharest, e-mail: traianc29@yahoo.com 


\section{Background and history}

Prostate-specific antigen is a glycoprotein serine protease secreted exclusively by the epithelial cells of the prostatic acini and ducts, being an organ-specific enzyme. Its structure contains a single-chain consisting of 240 amino acids $(93 \%)$ and 4 carbohydrates $(7 \%)$, with a molecular weight of 33,000 daltons. Structurally, the enzyme is similar to other serine proteases belonging to the kallikreins group.

The physiological role of PSA has not been fully established. Besides its action of serine protease, studies have shown that PSA also functions as an arginine esterase, having effects similar to chemotrypsins and trypsins (1). After secretion into the prostatic ducts, PSA reaches seminal plasma in high concentrations, acting on seminogelin (one of the major proteins secreted by seminal vesicles - with the effect of formation of semen coagulum), causing the lysis of this coagulum and the release of sperm $(2,3)$.

PSA discovery was the result of researches conducted in the 70's that were aimed at highlighting specific proteins in seminal and ejaculatory fluid, with forensic use. Later, in 1979, the purification of PSA from prostate tissue was succeeded (4), and in 1980 the PSA measurement technique in blood plasma was completed by ELISA method (5). For patients diagnosed with prostate cancer, the levels of serum prostate-specific antigen have been shown to be increased compared with healthy men (6). In the late 80 's PSA was introduced as a screening test for prostate cancer (PC) and as an investigation it was meant to assess the efficacy of surgical or hormonal treatment for this condition (7-9). In 1986, the U.S. Food and Drug Administration (FDA) approved the use of PSA as a marker of prostate cancer.

In serum, prostate-specific antigen molecules may be in a free form - free PSA - or in a complex form, bound to $\alpha 1$ antichymotryp-
sin-PSA-ACT (an endogenous inhibitor of serine proteases), $\alpha 2$ macroglobulin- PSA-A2M, in complex with the inhibitor of protein C-PSAPC, $\alpha 1$ antitrypsin-PSA-AT and inter $\alpha$-antitrypsin-PSA-ITI $(10,11)$. The predominant complex forms are PSA-ACT and PSA-A2M. Currently only PSA-ACT and free PSA are measurable, both having immunoreactivity. PSA-ACT may represent $60-95 \%$ of total PSA, while free-PSA between $5 \%$ and $35 \%$ (11). In prostate cancer, the amount of PSA-ACT released into the blood is higher compared with benign prostate diseases, and the free/ total PSA ratio is significantly lower $(11,12)$.

\section{Normal levels of serum PSA}

The importance of serum PSA derives from the fact that it is a better predictor of prostate cancer than information obtained by digital rectal examination and transrectal prostatic ultrasound (13), (14), especially in early stages of the disease (15).

Initially the maximum normal value was $4 \mathrm{ng} / \mathrm{ml}$, but it was found that at lower values the incidence of prostate cancer is also significant (for PSA values between 2.1 and $3 \mathrm{ng} /$ $\mathrm{ml}-23.9 \%$, and for values between $3.1-4 \mathrm{ng} /$ $\mathrm{ml}-26.9 \%$ ) (16). These values are particularly significant in "young" patients aged between 50 and 66 years, because for them, when the disease is diagnosed at an early stage, the treatment is curative.

The upper limit of normal serum PSA value currently proposed is $2.5 \mathrm{ng} / \mathrm{ml}$, but this value is not generally accepted. However, the detection rate of prostate cancer in patients with PSA levels between 2.5 and $4 \mathrm{ng} / \mathrm{ml}(27.48 \%)$ is comparable to the interval $4-10 \mathrm{ng} / \mathrm{ml} \mathrm{(30.08 \% )} \mathrm{(17),}$ which means that a significant number of cases of PC may escape diagnosis if the old upper limit is considered. The counter-arguments of the objectors to the decrease of the limit of normal PSA 
levels are: increase in the number of prostate biopsies with negative results, over-diagnosis of prostate cancer and consequently excessive treatment, economic reasons.

Today, the first determination of serum PSA is recommended to be performed at the age of 40 and then to be repeated every year (18). On the other hand, the American Urological Association does not support performing routine screening in patients belonging to the age group 40-54 and in those over 70 years (19). In patients aged 75 years and older who have had previous values of serum PSA less than $3 \mathrm{ng} / \mathrm{ml}$, the annual screening is no longer needed, as they are considered unlikely to develop aggressive prostate cancer or to die because of this disease (20). As a complementary measure to serum PSA determination, as part of the prostate cancer screening, a digital examination of the prostate should be performed as well.

\section{Factors influencing serum PSA levels}

Although the main cause of increase of PSA levels is prostate cancer, its values can be modified by other factors as well.

Digital rectal examination and transrectal ultrasonography of prostate cause transient increases in PSA values, but not significant changes. However, PSA measurement is recommended to be performed in such cases 72 hours after the maneuvers (11).

Significant changes also occur after cystoscopic examination, bladder catheterization, complete urinary retention, with elevations in PSA levels of 4 to 10 times, and episodes of acute prostatitis, prostatic ischemic necrosis, transurethral resection of the prostate and prostatic biopsy may increase PSA levels up to 50 times. In these situations, PSA determination is beneficial to be performed after 2-4 weeks (11). The so high waiting range for an objective determination of PSA is due to its relatively high half-life of $3.2+/-0.1$ days (9) and $2.2+/-0.8$ days (21).

Ejaculation in young men does not influence serum PSA levels, but in patients over 50 years (who are included in the screening group for prostate cancer), transient increases in PSA levels have been noticed after sexual activity. PSA measurement is recommended to be performed after a period of abstinence of 48-72 hours (22).

Benign prostatic hyperplasia $(\mathrm{BPH})$ is another cause of increased PSA levels. If in the case of healthy men, the annual growth rate of PSA levels is $0.04 \mathrm{ng} / \mathrm{ml}$ per year, in patients aged between 60 and 85 years, suffering from this condition, it can reach up to $0.27 \mathrm{ng} / \mathrm{ml}$ (23). A gram of adenomatous tissue is deemed to cause an increase in PSA by approximately $0.12 \mathrm{ng} / \mathrm{ml}$ (24).

Increased PSA level in benign or malignant prostate diseases is explained by the release of increased amounts of antigen from the glandular epithelium into circulation.

PSA production is androgen-dependent. Drug therapies affecting production of androgen hormones and metabolism will cause decrease in PSA levels. $5 \alpha$ reductase inhibitors (finasteride Proscar, dutasteride - Avodart), used in the treatment of BPH, have the side effect of reducing PSA levels by app. $50 \%$, an effect that occurs after 6 months of treatment. In these patients, the measured PSA levels must be doubled to obtain the real values of this indicator.

Transurethral resection of the prostate (TUR-P) and transvesical adenomectomy, BPH treatment methods, have the effect of long-term decrease in PSA.

Radical surgery treatment (radical prostatectomy, external radiotherapy or brachytherapy) and hormonal treatment for PC have as a result a decrease in PSA levels.

In all these cases, the decrease in PSA production is due to a reduction in the volume of prostate epithelium and in the amount of PSA produced per cell (1). 


\section{Serum PSA in prostate cancer detection}

Positive predictive value of serum PSA in detecting prostate cancer significantly increases the range in which this is found. For the range between 4 and $10 \mathrm{ng} / \mathrm{ml}$, it varies between 21 and $32 \%$ and for values between 10 and $20 \mathrm{ng} /$ $\mathrm{ml}$, it reaches $60-80 \%(1)$.

The range $2.5-10 \mathrm{ng} / \mathrm{ml}$ is considered the "gray zone" of PSA detection. Among patients with PSA levels between these values, only about $25-30 \%$ will be diagnosed with prostate cancer; the others have benign diseases. There have been described various methods for increasing PSA specificity and thus reducing the number of unnecessary prostate biopsies.

PSA velocity index (PSA velocity). PSA velocity refers to the growth rate of serum PSA measured every year. The concept was introduced in practice 20 years ago. It is considered that a value of PSA velocity greater than $0.75 \mathrm{ng} /$ $\mathrm{ml} /$ year is suggestive of the presence of prostate cancer (23). The European Association of Urology Guidelines mention that PSA velocity and another notion - PSA-DT (PSA doubling time) < 2 years are associated with a prognostic role in patients already diagnosed with PC, with limited utility in practice (25) For a proper appreciation of PSA velocity, the minimum follow-up period is considered to be 2 years, requiring annual serum PSA determination (11) .

PSA density (PSA-D). The concept appeared as a result of the observations that in prostate cancer there is produced an amount of PSA approximately 10 times higher than in benign diseases, per gram of prostate tissue $(8,26)$. PSA density is obtained by dividing the value of serum PSA by prostate volume. It was originally recommended an upper limit of normal PSA density of $0.15 \mathrm{ng} / \mathrm{ml} / \mathrm{cm}^{3}$ for PSA values between $4-10 \mathrm{ng} /$ $\mathrm{ml}$ and normal digital rectal prostate exam, but it was found that at this value half of the cases of prostate cancer remained undiagnosed (27). To improve the sensitivity of the method by up to $95 \%$ it is recommended to use different values of the upper limit of PSA-D depending on serum PSA levels: 0.05 for PSA between 2.5-4 ng/ $\mathrm{ml}, 0.1$ for PSA between $4-10 \mathrm{ng} / \mathrm{ml}$ and 0.19 for the range $10-19 \mathrm{ng} / \mathrm{ml}$ (28). The value of PSA density in usual practice is controversial because of the variables related to prostate volume measurement and the inability to determine the exact volume of prostatic epithelial tissue (the only producer of PSA).

The value of PSA density in prostate cancer screening can be improved by determining PSA D-TZ (PSA density corresponding to prostate transition zone). Benign prostatic hypertrophy has as an origin this prostatic zone and prostate cancer develops from the periphery. PSA D-TZ represents the serum PSA in relation to the transition zone volume (which is measured using transrectal ultrasound). Using PSA D-TZ for serum PSA values between $4-10 \mathrm{ng} / \mathrm{ml}$, the detection rate of prostate cancer was $97-100 \%$ and the number of unnecessary punctures approximately $20 \%$ (11). The method is however limited by the difficulty of accurately determining the transition zone volume.

Free/total PSA ratio (f/t PSA). In prostate cancer, PSA in complex form is found in greater quantity, compared with benign diseases. This translates into a low free/total PSA ratio. Considering $25 \%$ as the cut-off value of the f PSA / PSA-T ratio, the detection rate of prostate cancer was $95 \%$, with a decrease in the number of biopsies by $20 \%$, in patients with PSA values between $4-10 \mathrm{ng} / \mathrm{ml}$, with no changes at the digital rectal examination (29). $56 \%$ of patients with $\mathrm{f} / \mathrm{t}$ PSA $<10 \%$ were diagnosed with prostate cancer while this was met only in $8 \%$ of patients with $\mathrm{f} / \mathrm{t}$ PSA $>25 \%$.

For total PSA values in the range 2.5-4 ng/ $\mathrm{ml}$, a cut-off value of the free/total PSA ratio of $27 \%$ allowed a positive diagnosis in $90 \%$ of the cases (30). 
It is recommended that $\mathrm{f} / \mathrm{t}$ PSA be used for patients with prostate volume below $40 \mathrm{cc}$. For very high prostate volumes the sensitivity of the method decreases, requiring an adjustment of the cut-off value (31).

Free PSA molecules show a greater instability at room temperature and at refrigeration temperature $\left(4^{\circ} \mathrm{C}\right)$ compared with complex forms. For a correct measurement, the samples must be processed and centrifuged within maximum 2 hours of sampling. Keeping centrifuged serum for a period longer than 24 hours should be done at $-70^{\circ} \mathrm{C}(1)$. For this reason some authors challenge the free PSA value in the absence of using a standardized protocol for measuring it (1). U.S. Food and Drug Administration accepts and recommends using free PSA to detect prostate cancer in patients with PSA levels between 4 and $10 \mathrm{ng} / \mathrm{ml}$.

Correlation between normal PSA range and patient age. Increased serum PSA level is related to patient age and occurrence of benign prostatic hypertrophy. In order to avoid unnecessary punctures there have been proposed several normal reference ranges of PSA correlated with patient ages: $0-2.5 \mathrm{ng} / \mathrm{ml}$ for the age group 40-49 years, $0-3.5 \mathrm{ng} / \mathrm{ml}$ for group 50-59 years, $0-4.5 \mathrm{ng} / \mathrm{ml}$ for group 60-69 years and 0-6.5 $\mathrm{ng} / \mathrm{ml}$ for group 70-79 years (32). If for the first two age categories this method increased the detection rate of $\mathrm{PC}$, for the last two categories non-diagnosis of cases of malignancies was noticed in a significant percentage, $8 \%$ and $47 \%$ respectively (33).

Using PSA reference values correlated with age is not mentioned in the European Association of Urology Guidelines, the American Urological Association Guidelines or by the U.S. Food and Drug Administration.

In the later years, a urine genetic biomarker was introduced in order to improve the prostate cancer detection - PCA3 (prostate cancer gene 3). Studies showed better detection rate than PSA and free PSA; it represents an important prediction factor for prostate cancer in patients with previous negative biopsies (24), (34). It is approved by U. S. Food and Drug Administration and it is mentioned in the European Association of Urology Guidelines. Its main disadvantage is the cost, a PCA3 detection being approximately 40 times more expensive than a PSA test.

Other possible markers for prostate cancer are represented by MicroRNA's (miRNA's), which are gene expression regulators. They can be found in plasma, serum or urine. Some circulating miRNA's - miR-141 and miR-375 were associated with systemic prostate cancer (35), while those present in urine - miR-107 and miR574-3p had a diagnostic value for prostate cancer higher than PCA3 (35). Large studies are necessary in order to establish if the miRNA's can be used as screening methods for prostate cancer.

\section{Conclusions}

Although still widely debated some 20 years after its introduction in practice, the use of serum PSA and its derivatives in prostate cancer screening has two generally recognized effects: a significant increase in the detection rate of PC in early stages and a $20 \%$ to $50 \%$ decrease in the mortality due to this disease (36). The contestants of prostate cancer screening consider that the PSA introduction in daily practice increased the number of unnecessary biopsies and also the number of diagnosed patients with low risk disease, which were exposed to harmful and expensive treatments, with important side effects and quality of life alterations and without significant modifications of their life expectancy (37).

Nowadays, both European Association of Urology and American Urological Association Guidelines do not recommend the mass screening for prostate cancer anymore, but the early detection of the disease is still a crucial step for the patients with average and high risk.

Until the discovery of new and more accu- 
rate screening methods, serum PSA remains the most accessible tool for the assessment of patients in view of detecting prostate cancer.

\section{Bibliography}

1. Gretzer MB, Partin AW. Chapter 93. Prostate cancer tumor markers. In: Wein AJ, ed. Campbell-Walsh Urology. 9th ed. Philadelphia, PA: Saunders; 2007;2896-906.

2. Watt KW, Lee PJ, M'Timkulu T, Chan WP, Loor R. Human prostate-specific antigen: structural and functional similarity with serine proteases. Proc Natl Acad Sci U S A. 1986 May;83(10):3166-70. DOI: 10.1073/ pnas.83.10.3166

3. Lilja H, Laurell CB. The predominant protein in human seminal coagulate. Scand J Clin Lab Invest. 1985 Nov;45(7):635-41. DOI: 10.3109/00365518509155271

4. Wang MC, Valenzuela LA, Murphy GP, Chu TM. Purification of a human prostate specific antigen. Invest Urol. 1979 Sep;17(2):159-63.

5. Kuriyama M, Wang MC, Papsidero LD, Killian CS, Shimano T, Valenzuela L, et al. Quantitation of prostate specific antigen in serum by a sensitive enzyme immunoassay. Cancer Res. 1980 Dec;40(12):4658-62.

6. Kuriyama M, Wang MC, Lee CI, Papsidero LD, Killian $\mathrm{CS}$, Inaji $\mathrm{H}$, et al. Use of human prostate-specific antigen in monitoring prostate cancer. Cancer Res. 1981 Oct;41(10):3874-6.

7. Seamonds B. Reference intervals for prostate-specific antigen. Clin Chem. 1988 Jun;34(6):1366-7.

8. Stamey TA, Yang N, Hay AR, McNeal JE, Freiha FS, Redwine E. Prostate-specific antigen as a serum marker for adenocarcinoma of the prostate. N Engl J Med. 1987 Oct 8;317(15):909-16. DOI: 10.1056/ NEJM198710083171501

9. Oesterling JE, Chan DW, Epstein JI, Kimball AW Jr, Bruzek DJ, Rock RC, et al. Prostate specific antigen in the preoperative and postoperative evaluation of localized prostatic cancer treated with radical prostatectomy. J Urol. 1988 Apr;139(4):766-72.

10. Lilja H, Christensson A, Dahlén U, Matikainen MT, Nilsson O, Pettersson K, et al. Prostate-specific antigen in serum occurs predominantly in complex with alpha 1-antichymotrypsin. Clin Chem. 1991 Sep;37(9):161825.

11. Ambert V. Diagnosticul in cancerul de prostata, Bucuresti, Editura Universitara Carol Davila, Bucuresti. 2011;74-93.

12. Christensson A, Björk T, Nilsson O, Dahlén U, Matikainen MT, Cockett AT, et al. Serum prostate specific antigen complexed to alpha 1-antichymotrypsin as an indicator of prostate cancer. J Urol. 1993 Jul;150(1):1005.

13. Catalona WJ, Richie JP, Ahmann FR, Hudson MA,
Scardino PT, Flanigan RC, et al. Comparison of digital rectal examination and serum prostate specific antigen in the early detection of prostate cancer: results of a multicenter clinical trial of 6,630 men. J Urol. 1994 May;151(5):1283-90.

14. Stanciu AE. Clinical applications of total PSA and free PSA tumor markers. Rev Romana Med Lab. 2005;1(1):33-7.

15. Dema A, Taban SM, Lazar E, Anderco D, Loghin A, Lazureanu C, et al. Alpha-methylacyl-CoA-racemase expression in variants and unusual patterns of prostate carcinoma. Rev Romana Med Lab. 2011;19(4):319-31.

16. Thompson IM, Pauler DK, Goodman PJ, Tangen CM, Lucia MS, Parnes HL, Minasian LM, Ford LG, Lippman SM, Crawford ED, Crowley JJ, Coltman CA Jr. Prevalence ofprostate cancer among men with a prostate-specific antigen level $<$ or $=4.0 \mathrm{ng}$ per milliliter. N Engl J Med. 2004 May 27;350(22):2239-46. DOI: 10.1056/NEJMoa031918

17. Gilbert SM, Cavallo CB, Kahane H, Lowe FC. Evidence suggesting PSA cutpoint of $2.5 \mathrm{ng} / \mathrm{mL}$ for prompting prostate biopsy: review of 36,316 biopsies. Urology. 2005 Mar;65(3):549-53. DOI: 10.1016/j.urology.2004.10.064

18. Börgermann C, Loertzer H, Hammerer P, Fornara P, Graefen M, Rübben H. Problems, objective, and substance of early detection of prostate cancer. Urologe A. 2010 Feb;49(2):181-9. DOI: 10.1007/s00120-0102234-7

19. www.auanet.org/education/guidelines/prostate-cancer-detection.cfm

20. Schaeffer EM, Carter HB, Kettermann A, Loeb S, Ferrucci L, Landis $\mathrm{P}$, et al. Prostate specific antigen testing among the elderly--when to stop? J Urol. 2009 Apr;181(4):1606-14; discussion 1613-4. DOI: 10.1016/j.juro.2008.11.117

21. Stamey TA, Yang N, Hay AR, McNeal JE, Freiha FS, Redwine E. Prostate-specific antigen as a serum marker for adenocarcinoma of the prostate. N Engl J Med. 1987 Oct 8;317(15):909-16. DOI: 10.1056/ NEJM198710083171501

22. Herschman JD, Smith DS, Catalona WJ. Effect of ejaculation on serum total and free prostate-specific antigen concentrations. Urology. 1997 Aug;50(2):239-43. DOI: 10.1016/S0090-4295(97)00209-4

23. Carter HB, Pearson JD, Metter EJ, Brant LJ, Chan DW, Andres R, Fozard JL,Walsh PC. Longitudinal evaluation of prostate-specific antigen levels in men with and without prostate disease. JAMA. 1992 Apr 22-29;267(16):2215-20. DOI: 10.1001/ jama.1992.03480160073037

24. Sinescu I, Chibelean C, Cerempei V, Dudu C, Iordache A, Voinea S, et al. Cancerul de prostată. In Sinescu I, Gluck G. Tratat de Urologie, 1st edition, 3rd volume, Editura Medicala, Bucuresti. 2008;2376-8. 
25. Heidenreich A, Bastian PJ, Bellmunt J, Bolla M, Joniau $\mathrm{S}$, Mason MD, et al. In Guidelines on Prostate Cancer, European Association of Urology Guidelines, Drukkerij Gelderland, Arnhem. 2013;16-17.

26. Stamey TA, Kabalin JN, McNeal JE, Johnstone IM, Freiha F, Redwine EA, et al. Prostate specific antigen in the diagnosis and treatment of adenocarcinoma of the prostate. II. Radical prostatectomy treated patients. J Urol. 1989 May;141(5):1076-83.

27. Catalona WJ, Richie JP, deKernion JB, Ahmann FR, Ratliff TL, Dalkin BL, et al. Comparison of prostate specific antigen concentration versus prostate specific antigen density in the early detection of prostate cancer: receiver operating characteristic curves. J Urol. 1994 Dec;152(6 Pt 1):2031-6.

28. Stephan C, Stroebel G, Heinau M, Lenz A, Roemer A, Lein $\mathrm{M}$, et al. The ratio of prostate-specific antigen (PSA) to prostate volume (PSA density) as a parameter to improve the detection of prostate carcinoma in PSA values in the range of $<4 \mathrm{ng} / \mathrm{mL}$. Cancer. $2005 \mathrm{Sep}$ 1;104(5):993-1003. DOI: 10.1002/cncr.21267

29. Catalona WJ, Partin AW, Slawin KM, Brawer MK, Flanigan RC, Patel A, et al. Use of the percentage of free prostate-specific antigen to enhance differentiation of prostate cancer from benign prostatic disease: a prospective multicenter clinical trial. JAMA. 1998 May 20;279(19):1542-7. DOI: 10.1001/jama.279.19.1542

30. Djavan B, Zlotta A, Kratzik C, Remzi M, Seitz C, Schulman CC, et al. PSA, PSA density, PSA density of transition zone, free/total PSA ratio, and PSA velocity for early detection of prostate cancer in men with serum PSA 2.5 to $4.0 \mathrm{ng} / \mathrm{mL}$. Urology. $1999 \mathrm{Sep} ; 54(3): 517-$ 22. DOI: $10.1016 / \mathrm{S} 0090-4295(99) 00153-3$
31. Stephan C, Lein M, Jung K, Schnorr D, Loening SA. The influence of prostate volume on the ratio of free to total prostate specific antigen in serum of patients with prostate carcinoma and benign prostate hyperplasia. Cancer. 1997 Jan 1;79(1):104-9. DOI: 10.1002/(SICI) 1097-0142(19970101)79:1<104::AID-CNCR15>3.0. $\mathrm{CO} ; 2-8$

32. Oesterling JE, Jacobsen SJ, Chute CG, Guess HA, Girman CJ, Panser LA, et al. Serum prostate-specific antigen in a community-based population of healthy men. Establishment of age-specific reference ranges. JAMA. 1993 Aug 18;270(7):860-4. DOI: 10.1001/ jama.1993.03510070082041

33. Catalona WJ, Hudson MA, Scardino PT, Richie JP, Ahmann FR, Flanigan RC, et al. Selection of optimalprostate specific antigen cutoffs for early detection of prostate cancer: receiver operating characteristic curves. J Urol. 1994 Dec;152(6 Pt 1):2037-42.

34. Auprich M, Bjartell A, Chun FK, de la Taille A, Freedland SJ, Haese A, et al. Contemporary role of prostate cancer antigen 3 in the management of prostate cancer. Eur Urol. 2011 Nov;60(5):1045-54. DOI: 10.1016/j. eururo.2011.08.003

35. Sapre N, Selth LA. Circulating MicroRNAs as Biomarkers of Prostate Cancer: The State of Play. Prostate Cancer. 2013 Mar 12;2013:e539680. DOI: $10.1155 / 2013 / 539680$

36. Heidenreich A, Bastian PJ, Bellmunt J, Bolla M, Joniau $\mathrm{S}$, Mason MD, et al. In Guidelines on Prostate Cancer, European Association of Urology Guidelines, Drukkerij Gelderland, Arnhem. 2013;14-15.

37. Wilt TJ, Ahmed HU. Prostate cancer screening and the management of clinically localized disease. BMJ. 2013 Jan;346:f325. DOI: 10.1136/bmj.f325 